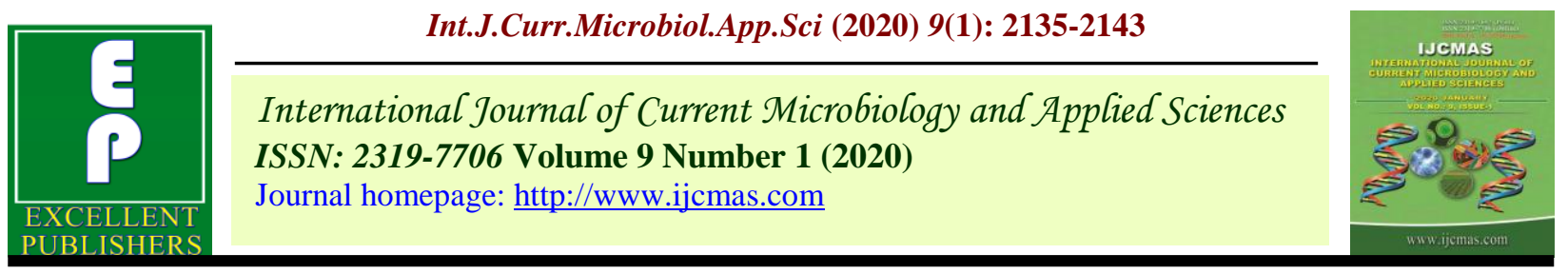

Original Research Article

https://doi.org/10.20546/ijcmas.2020.901.243

\title{
Situational Analysis of Farmers on Knowledge and Use of ICT in Agriculture and Allied Sectors
}

\author{
S. G. Puri ${ }^{1 *}$, C. M. Bellurkar ${ }^{2}$ and S. G. More ${ }^{3}$ \\ All India Coordinated Research Project-Home Science, Dept. of Home Science Extension \& \\ Communication Management, College of Home Science, VNMKV, Parbhani (MS), India \\ *Corresponding author
}

\begin{tabular}{|l|}
\hline Ke y w o r d s \\
Farmers, Access, \\
Availability, \\
Awareness, Use, \\
Attitude
\end{tabular}

\section{A B S T R A C T}

Present investigation was carried out in Parbhani district of Maharashtra. The study was conducted in 5 villages viz., Asola, Karegaon, Pandhari, Nandgaon (Bk.) and Nandgaon (Kh.) of Parbhani block. From these villages twenty farmers each village, totally 100 farmers were interviewed. The data were collected personally by using the structured interview schedule. Findings of the study revealed that television was available to majority (93.00) per cent of the farmers from which 68.00 per cent had complete access to it. Mobile phones were available to a huge majority ( 98.00 per cent) of the farmers and 51.00 per cent had partial access to it. Cent per cent of the farmers were aware about calling mobile without internet while 46.93 per cent of them were using it. A huge majority (93.87 per cent) of the farmers were aware about SMSs and less than one third (30.61 per cent) could use it. More than half of the farmers were using memory stick (59.18 per cent), Whats app (56.12 per cent), Facebook (52.04 per cent). It was noted that 83.67 per cent of the farmers were aware of accessing different internet sites while 51.02 were using it. Frequency of use television by 59.00 per cent of the farmers was sometimes whereas mobile was used regularly by a huge majority ( 95.00 per cent) of them. Use of internet by 37.00 per cent of the farmers was regular. More than three fourth (82.00 per cent) of the farmers had favourable attitude whereas 11.00 per cent had highly favourable attitude towards use of ICT.

\section{Introduction}

Today is the era of Information Communication Technology (ICT). Various ICT tools are used to educate and inform the rural people. For generations, rural people have been living in complete isolation without much access to modern media of communication. The development of a society largely depends on the access to information. 
ICTs are a diverse set of technological tools and resources to create, store, generate value and manage information. It consists of segments as diverse as telecommunications, radio and television broadcasting, computer hardware, software and services and electronic media.

The ICTs in recent years have witnessed major changes and are emerging as a powerful tool for accelerating agricultural growth in a developing country like India.

There has been a rapid growth in the ICT sector since the late 1980s and the use of ICT has dramatically expanded since the 1990s.

Information and communication technologies (ICTs) can facilitate access to timely and accurate information for an improved agricultural production. ICTs, especially mobile applications, are playing key role in facilitating access to resources by the poor. The "digital financial services" revolution has huge implication on family farmers.

With the increasing penetration of mobile phones in remote parts of the world, efforts should then be made to strengthen the innovative use of mobile technologies by family farmers. Combination of mobile technology and geographic information system provide accurate, specific/micro information of soil, water, nutrient etc. on farmers' field for decision making.

Most of the family farmers in developing countries live rural areas and are in most cases divorced from technology and vital agricultural support services needed to carry out farming activities.

Providing farmers with (i) timely and relevant information; (ii) access to credit; and (iii) better market prices could go a long way in addressing global poverty and improving agricultural productivity.

The aspect of timely and relevant information, especially with the role of Information Communication and Technology to connect farmers with the information they need has received much attention in the last decade.

This study examines the extent of farmers' access to ICTs, the use of ICTs by the farmers, attitude of farmers towards ICTs etc. The present research study was conducted under the objective include to conduct situational analysis on knowledge and use of ICT in agriculture and allied sectors.

\section{Materials and Methods}

Situational analysis on knowledge and use of ICT in agriculture and allied sectors was conducted for the male farmers. Present investigation was carried out in Parbhani District from Marathwada region of Maharashtra State. From Parbhani block five villages Asola, Pandhari, Karegaon, Nandgaon (Bk.) and Nandgaon (Kh.) were selected. From these villages twenty farmers each village, totally 100 farmers were interviewed. The data were collected personally by using the structured interview schedule.

\section{Results and Discussion}

As regards availability and accessibility to different ICT hardware by the farmers, it is illustrated from table 1 that television was available to majority (93.00) per cent of the farmers from which 68.00 per cent had complete and 17.00 per cent had partial access to it. It was noted that Radio was available and partially accessible to 2.00 per cent of the farmers whereas mobile was available to (98.00) per cent of the farmers. It is further noticed that 30.00 per cent of the 
farmers had complete access and more than half (51.00 per cent) had partial access to mobile. Nobody had availability and access to Kiosk/common service centers. Computers were available to 5.00 per cent of the farmers while 3.00 and 2.00 per cent of the farmers had complete and partial access to it. Availability of CD/DVD was for only 4.00 percent of farmers and 2.00 per cent of each had complete and partial access to it respectively. More than half (56.00 per cent) of the farmers were having availability to internet whereas 30.00 and 26.00 percent of the farmers had complete and partial access to it respectively. Availability of e-mail was for 9.00 per cent of the farmers while 4.00 and 5.00 per cent had complete and partial accessibility to e-mail respectively.

These results are in line with the studies of Ansari and Pandey (2011), Chhachhar et al., (2014), Ferris et al., (2008), Gupta (2005), Hassan et al., (2008), Munyua (2000), Okello et al., (2010), Olaniyi (2013), One World Foundation India (2012), Rebekka Syiem et al., (2015) and Sharma et al., (2012).

It was noted from the table 2 that, majority (98.00 per cent) of the farmers had their own mobiles while only 02.00 per cent of them did not own the mobiles.

Awareness and use of the social networking sites like, Whats app and Facebook were also studied (Table 3). It was observed that 58.16 per cent of the farmers were aware of Whats app and Facebook while 56.12 and 52.04 per cent of them could use it respectively. Less than one fourth ( 24.48 per cent) of the farmers having mobile with internet facility, were aware about the games movies/songs on the mobile and 20.40 per cent were found to be using the same. It was noticed that awareness of 83.67 per cent of the farmers was for accessing different internet sites while it was actually used by only 51.02 per cent of them.

Table.1 Distribution of respondents according to availability and accessibility to different ICT hardware

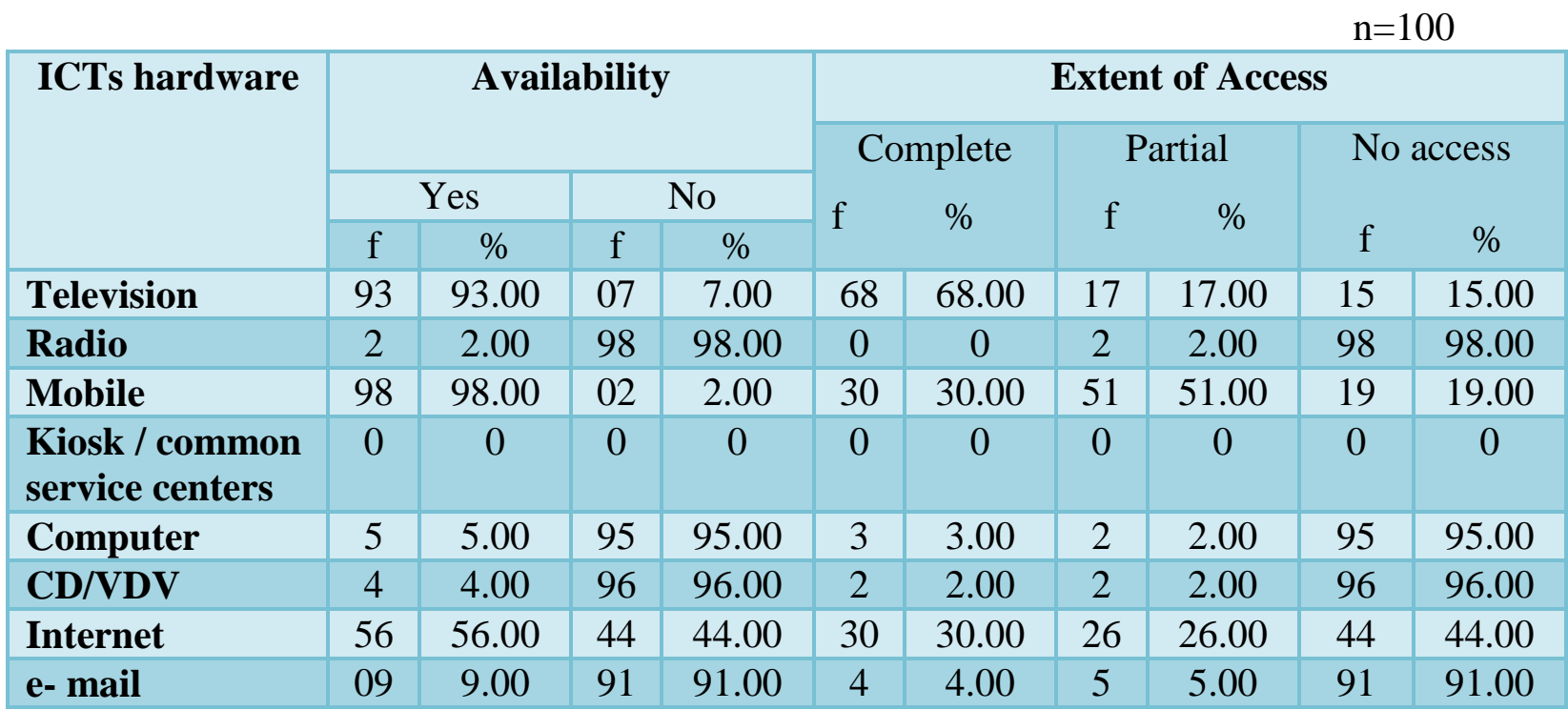


Table.2 Per cent distribution of respondents according to their ownership of Mobile

\begin{tabular}{|c|c|c|c|c|}
\hline & \multicolumn{3}{c}{ Ownership of mobile } & $\mathrm{n}=100$ \\
\hline & Yes & & & No \\
\hline $\mathbf{f}$ & & $\%$ & $\mathrm{f}$ & $\%$ \\
\hline $\mathbf{9 8}$ & 98.00 & 2 & 2.00 \\
\hline
\end{tabular}

Table.3 Per cent distribution of respondents according to their Awareness \& use of different ICT tools \& services

\begin{tabular}{|c|c|c|c|c|c|c|c|c|}
\hline \multirow{3}{*}{$\begin{array}{l}\text { ICT tools and services } \\
\begin{array}{l}\text { Mobile without internet } \\
(\mathrm{n}=98)\end{array}\end{array}$} & \multicolumn{4}{|c|}{ Aware } & \multicolumn{4}{|c|}{ Use } \\
\hline & \multicolumn{2}{|c|}{ Yes } & \multicolumn{2}{|c|}{ No } & \multicolumn{2}{|c|}{ Yes } & \multicolumn{2}{|c|}{ No } \\
\hline & $\mathrm{f}$ & $\%$ & $\mathrm{f}$ & $\%$ & $\mathrm{f}$ & $\%$ & $\mathrm{f}$ & $\%$ \\
\hline Calling & 98 & 100.00 & 0 & 0 & 46 & 46.93 & 52 & 53.06 \\
\hline SMS & 92 & 93.87 & 6 & 6.12 & 30 & 30.61 & 68 & 69.38 \\
\hline Memory stick/card & 61 & 62.24 & 37 & 37.75 & 8 & 8.16 & 90 & 91.83 \\
\hline \multicolumn{9}{|c|}{ Mobile with internet $(\mathbf{n}=98)$} \\
\hline Calling & 58 & 59.18 & 40 & 40.81 & 58 & 59.18 & 40 & 40.81 \\
\hline SMS ing & 58 & 59.18 & 40 & 40.81 & 58 & 59.18 & 40 & 40.81 \\
\hline Memory stick/card & 58 & 59.18 & 40 & 40.81 & 58 & 59.18 & 40 & 40.81 \\
\hline Whats app & 57 & 58.16 & 41 & 41.83 & 55 & 56.12 & 43 & 43.87 \\
\hline Facebook & 57 & 58.16 & 41 & 41.83 & 51 & 52.04 & 47 & 47.95 \\
\hline Games/ movies/ songs & 24 & 24.48 & 74 & 75.51 & 20 & 20.40 & 78 & 79.59 \\
\hline $\begin{array}{l}\text { Accessing different } \\
\text { internet sites }\end{array}$ & 82 & 83.67 & 16 & 16.32 & 50 & 51.02 & 48 & 48.97 \\
\hline \multicolumn{9}{|c|}{ Computer /laptop without internet $(n=100)$} \\
\hline $\begin{array}{l}\text { Office documents/ } \\
\text { presentations }\end{array}$ & 9 & 9.00 & 91 & 91.00 & 6 & 6.00 & 94 & 94.00 \\
\hline \multicolumn{9}{|c|}{ Computer/laptop with internet $(n=100)$} \\
\hline $\begin{array}{l}\text { Office documents/ } \\
\text { presentations }\end{array}$ & 10 & 10.00 & 90 & 90.00 & 4 & 4.00 & 96 & 96.00 \\
\hline Facebook, social media & 8 & 8.00 & 92 & 92.00 & 2 & 2.00 & 98 & 98.00 \\
\hline $\begin{array}{l}\text { Accessing different } \\
\text { internet sites }\end{array}$ & 5 & 5.0 & 95 & 95.00 & 2 & 2.00 & 98 & 98.00 \\
\hline
\end{tabular}


Table.4 Distribution of respondents according to pattern of use of mobile $(n=100)$

\begin{tabular}{|c|c|c|c|c|c|c|c|c|c|c|c|c|c|c|c|c|c|}
\hline \multicolumn{18}{|c|}{ Calls } \\
\hline \multirow{4}{*}{$\begin{array}{l}\text { 1. Answering } \\
\text { calls }\end{array}$} & \multicolumn{11}{|c|}{ All calls } & \multicolumn{6}{|c|}{ Known calls } \\
\hline & \multicolumn{6}{|c|}{ Yes } & \multicolumn{5}{|c|}{ No } & \multicolumn{4}{|c|}{ Yes } & \multicolumn{2}{|c|}{ No } \\
\hline & \multicolumn{4}{|c|}{$\mathrm{F}$} & \multicolumn{2}{|c|}{$\%$} & & \multicolumn{2}{|l|}{$\mathrm{F}$} & \multicolumn{2}{|c|}{$\%$} & \multicolumn{2}{|c|}{$\mathrm{F}$} & \multicolumn{2}{|r|}{$\%$} & $\mathrm{~F}$ & $\%$ \\
\hline & \multicolumn{4}{|c|}{98} & \multicolumn{2}{|c|}{98.00} & \multicolumn{3}{|c|}{2} & \multicolumn{2}{|c|}{2.00} & \multirow{2}{*}{\multicolumn{2}{|c|}{0}} & \multicolumn{2}{|r|}{0} & 0 & \multirow[t]{2}{*}{0} \\
\hline \multicolumn{15}{|c|}{ SMS } & & & \\
\hline \multirow[t]{8}{*}{ 2. SMS received } & \multirow{4}{*}{\multicolumn{4}{|c|}{$\begin{array}{l}\text { Can you read } \\
\text { messages }\end{array}$}} & & & no, $t$ & an who & ads th & $\mathrm{m}$ for $\mathrm{y}$ & & & & & Read a & 11 messag & \\
\hline & & & & & & & & & & & & & & & Yes & & o \\
\hline & & & & & & & & & & & & & & $\mathrm{F}$ & $\%$ & $\mathrm{~F}$ & $\%$ \\
\hline & & & & & & & & & & & & & & 88 & 88.00 & 3 & 3.00 \\
\hline & & Yes & & No & Hus & and & & Idren & Rel & tives & & end & & $\begin{array}{l}\text { Read } \\
\text { numb }\end{array}$ & $\begin{array}{l}\text { message } \\
\text { ers }\end{array}$ & $\mathrm{s}$ from $\mathrm{k}$ & wn \\
\hline & $\mathrm{F}$ & $\%$ & $\mathrm{~F}$ & $\%$ & $\mathrm{~F}$ & $\%$ & $\mathrm{~F}$ & $\%$ & $\mathrm{~F}$ & $\%$ & $\mathrm{~F}$ & & 7 & & Yes & & Jo \\
\hline & & & & & & & & & & & & & & $\mathrm{F}$ & $\%$ & $\mathrm{~F}$ & $\%$ \\
\hline & 82 & 82.00 & 18 & 18.00 & 0 & 0 & 11 & 11.00 & 2 & 2.00 & 4 & & & 3 & 3.00 & 97 & 97.00 \\
\hline $\begin{array}{l}\text { 3. Source and } \\
\text { type of SMS }\end{array}$ & & Hus & and & & Chil & dren & & tives & & nds & & & & & $\begin{array}{l}\text { riculture } \\
\text { Dept. }\end{array}$ & $\begin{array}{c}\mathrm{Ar} \\
\text { (D } \\
\text { con }\end{array}$ & $\begin{array}{l}\text { other } \\
\text { ferent } \\
\text { oanies) }\end{array}$ \\
\hline & & $\mathrm{F}$ & & $\%$ & $\mathrm{~F}$ & $\%$ & $\mathrm{~F}$ & $\%$ & $\mathrm{~F}$ & $\%$ & $\mathrm{~F}$ & & 7 & $\mathrm{~F}$ & $\%$ & $\mathrm{~F}$ & $\%$ \\
\hline i) Voice & & 0 & & 0 & 0 & 0 & 2 & 2.00 & 2 & 2.00 & 0 & & ) & 0 & 0 & 0 & 0 \\
\hline ii) Written & & 0 & & 0 & 2 & 2.00 & 40 & 40.00 & 39 & 39.00 & 0 & & ) & 0 & 0 & 84 & 84.00 \\
\hline iii) Video & & 0 & & 0 & 2 & 2.00 & 28 & 28.00 & 29 & 29.00 & 0 & & ) & 0 & 0 & 0 & 0 \\
\hline 4. SMS sent & & & an $y$ & ou write & messą & & & & & If $\mathrm{n}$ & , than & ho & vrite & them $\mathrm{f}$ & for you & & \\
\hline & & & & & & No & & Husb & and & & iildre & & & Relativ & & Fric & \\
\hline & & $\mathrm{F}$ & & $\%$ & $\mathrm{~F}$ & & $\%$ & $\mathrm{~F}$ & $\%$ & $\mathrm{~F}$ & & & $\mathrm{~F}$ & & $\%$ & $\mathrm{~F}$ & $\%$ \\
\hline & & 79 & & 9.00 & 21 & & .00 & 0 & 0 & 10 & & & 2 & & 2.00 & 4 & 4.00 \\
\hline & & & & & & Me & mory & tick/mel & lory c & & & & & & & & \\
\hline 5. Capacity of & & $2 c$ & & & & $4 \mathrm{~GB}$ & & & $8 \mathrm{GI}$ & & & & $6 \mathrm{~GB}$ & & & $32 \mathrm{G}$ & \\
\hline $\begin{array}{l}\text { memory stick } \\
\text { /card } \quad(n=53)\end{array}$ & & 11 & & 1.00 & 13 & & 13.00 & 7 & & 7.00 & & 18 & & 18.00 & & 4 & 4.00 \\
\hline
\end{tabular}


Table.5 Distribution of respondents according to frequency of use of different ICT tools

\begin{tabular}{|l|c|c|c|c|c|c|c|c|}
\hline \multicolumn{1}{|c|}{ ICT tools } & \multicolumn{9}{|c|}{ Frequency of usage } & \multicolumn{2}{c|}{$\mathrm{n}=100$} \\
\hline & \multicolumn{2}{|c|}{ Always } & \multicolumn{2}{c|}{ Sometimes } & \multicolumn{2}{c|}{ Rarely } & \multicolumn{2}{c|}{ Never } \\
\hline & $\mathbf{f}$ & $\mathbf{\%}$ & $\mathbf{f}$ & $\mathbf{\%}$ & $\mathbf{f}$ & $\mathbf{\%}$ & $\mathbf{f}$ & $\%$ \\
\hline Television & 26 & 26.00 & 59 & 59.00 & 11 & 11.00 & 4 & 4.00 \\
\hline Radio & 0 & 0 & 2 & 2.00 & 0 & 0 & 98.00 & 98.00 \\
\hline Mobile & 95 & 95.00 & 1 & 1.00 & 2 & 2.00 & 2 & 2.00 \\
\hline $\begin{array}{l}\text { Kiosk / common } \\
\text { service centers }\end{array}$ & 0 & 0 & 0 & 0 & 0 & 0 & 0 & 0 \\
\hline Computer & & & & & & & & \\
\hline CD/VDV & 0 & 0 & 7 & 7.00 & 6 & 6.00 & 87 & 87.00 \\
\hline Internet & 37 & 37.00 & 8 & 4.00 & 0 & 0 & 96 & 96.00 \\
\hline e- mail & 3 & 3.00 & 3 & 3.00 & 11 & 11.00 & 44 & 44.00 \\
\hline
\end{tabular}

Table.6 Overall attitude of respondents towards ICT

\begin{tabular}{|l|c|c|c|c|c|}
\hline Category & Score range & Freq. & \% & Mean & SD \\
\hline Highly favorable & 50 to 59 & 11 & 11.00 & 52.363 & 3.0421 \\
\hline Favorable & 43 to 49 & 82 & 82.00 & 45.341 & 1.7862 \\
\hline Least favourable & 38 to 42 & 07 & 07.00 & 41.142 & 1.463 \\
\hline
\end{tabular}

Awareness of the farmers for the office documents/presentations, Facebook, social media and accessing different internet sites for computer/laptop without internet and computer/laptop with internet facility was found to be only within 9.00 and 10.00 per cent respectively whereas percentage for use for office documents/presentations etc. for computer/laptop without internet and computer/laptop with internet facility was 6.00 and 4.00 percent respectively.

These results were comparable with the studies of Batte et al., (1990), Emmanuel (2010), K. Lokeswari (2016), Mtega and Msungu (2013), Nakweya (2013), Narender and Anandaraja (2008), Nazari and Hasbullah (2008), Oyeyinka and Bello (2013), Rebekka Syiem, Saravanan Raj (2015), Shetto (2008) and Sife et al., (2010).
It is depicted from table no. 4 that 98.00 per cent of the farmers were able to answer for all the mobile calls and 82.00 per cent of them could read SMSs received to them while for others their children (11.00 per cent), relatives (2.00 per cent) and friends (4.00 per cent) were reading the messages.

All the messages received were read by 88.00 per cent of the farmers or by their family members and friends while only 3.00 per cent of the farmers were found to reading messages from known numbers. It can be noticed from the same table that about 2.00 per cent of the farmers received written messages from the children, about 40.00 per cent from the relatives, 39.00 per cent from the friends and 84.00 per cent from different companies. It was also noticed that no one of the farmers was receiving SMSs from KVKs or Agriculture Dept. It can be seen that 2.00 
per cent voice messages were received by the farmers from relatives and friends. It can be also noticed that 28.00 per cent of farmers received video messages from relatives and 29.00 per cent of farmers from friends and only 2.00 per cent of them received video messages from children. It was found that more than three fourth ( 79.00 per cent) of the farmers were able to send the text messages and for others, their children (10.00 per cent) or other relatives (2.00 per cent) and friends (4.00 per cent) were found to write the messages. It was also noticed that 53.00 per cent of the farmers had memory sticks or cards in their mobiles out of which 18.00 per cent had a memory card of 16 GB capacity. Capacity of memory card for 13.00 per cent of them was 4 GB followed by 11.00 per cent were using 2 GB capacity memory card in their mobiles. Only 7.00 per cent and 4.00 per cent of the farmers were found to be having 8 GB and 32 GB memory cards respectively for their mobiles.

Table 5 implies distribution of respondents according to frequency of use of different ICT tools. As far as the frequency of use television was concerned, it was observed that 59.00 per cent of the farmers were using it sometimes and 26.00 per cent were using it regularly while 11.00 per cent of them were using it rarely. Mobile was used regularly by a huge majority (95.00 per cent) of them. Use of mobile for sometimes was done by 1.00 per cent and rarely by 2.00 per cent of them. No one was found to be using facility of the Kiosk/common service centres. Frequency of use of Computer for sometimes and rarely was 7.00 and 6.00 per cent respectively. Use of CD/VDV was found sometimes by 4.00 per cent of the farmers. Internet was used always by 37.00 per cent, sometimes by 8.00 per cent and rarely by 11.00 per cent of them. Use of e-mails for various purposes was done always, sometimes and rarely by 3.00 per cent of the farmers.
Table 6 implies the attitude of the farmers towards ICT. It can be seen that more than three fourth (82.00 per cent) of the farmers had favourable attitude whereas 11.00 per cent had highly favourable attitude. It was also found that 7.00 per cent of them were having least favourable attitude towards ICT.

The result is supporting to the results of $\mathrm{K}$. Lokeswari (2016) and Khondokar Humayun Kabir (2015).

In conclusion, television was available to majority ( 93.00 per cent) of the farmers, out of which 68.00 per cent had complete and 17.00 per cent had partial access to it. Only 5.00 per cent the farmers had availability for Computers, 4.00 per cent for CD/DVD and Internet 56.00 per cent and e-mail facility 9.00 per cent. Nobody had availability and access to Kiosk/common service centres. Cent per cent of them were aware about calling of mobile without internet while less than half (46.93 per cent) of them were using it. A huge majority (93.87 per cent) of the farmers was having the knowledge about SMS and 30.61 per cent of them were actually doing SMSs. More than half (59.18 per cent) of the farmers, having mobile phones with internet facility were aware of calling the mobile, could use it, were found to have the knowledge about SMSing and were actually doing SMSs and they also had awareness of memory stick and were using the memory sticks. It was observed that 58.16 per cent of the farmers were aware of Whats app and 56.12 per cent were using it whereas 58.16 per cent of them aware about Facebook 52.04 per cent of them could use it. Majority of them (83.67 per cent) were aware about accessing different internet sites whereas more than half (51.02 per cent) were found to be using it. It can be seen that more than three fourth (82.00 per cent) of the farmers had favourable attitude whereas 11.00 per cent had highly favourable attitude. It was also 
found that 7.00 per cent of them were having least favourable attitude towards ICT.

\section{References}

Ansari, M.A. and Pandey, N. (2011) Assessing the potential and use of mobile phones by the farmers in Uttarakhand (India): A special project report. G.B. Pant University of Agriculture and Technology, Pantnagar, India.

Batte, M.T. Schnitkey, G.D. and Jones, E. (1990) Sources use and adequacy of marketing information for commercial mid western cash grain farmers, North Central Journal of Agricultural Economics, 12 :2, 187-196., doi: 10.1093/aepp/12.2.187

Chhachhar, A.R., Querestic, B., Khushk, G.M. and Ahmed, S. (2014). 'Impact of ICTs in Agriculture Development'. Journal of Basic Applied Scientific Research, 4:1, 281-288. http://www.textroad.com/pdf/JBASR/J. \%20Basic.\%20Appl.\%20Sci.\%20Res., $\% 204$ (1) 281-288,\% 202014.pdf.

Emmanuel, C.O. (2010) Differential mass media usage among rice farmers in Nigeria. Evidence from Benue State. Journal of Communication, 1:1, 33-36.

Ferris, S., Engoru, P. and Kaganzi, E. (2008) Making market information services work better for the poor in Uganda. CAPRi Working Paper No. 77: CGIAR System wide Program on Collective Action and Property Rights (CAPRi), Washington DC., doi: 10.2499/capriwp77

Gupta, D.K. (2005) Modern encyclopedia of media and mass communication. Rajat Publications, New Delhi, India.

Hassan, M.S., Hassan, M.A., Samah, B.A., Ismail, N. and Shafrill, H.A.M. (2008) Use of Information and Communication Technologies among agri-based entrepreneurs in Malaysia. http://www.cabi.org/gara/FullTextPDF/ 2008/20083298158.pdf.

Khondokar Humayun Kabir. (2015). 'Attitude and Level of Knowledge of Farmers on ICT based Farming' EUROPEAN ACADEMIC RESEARCH, II:10, 13177 $-13196$.

K. Lokeswari (2016). 'A Study of the Use of ICT among Rural Farmers' 6:3, July / September 2016, 232-238.

K. P. Raghuprasad, Devaraja S.C and Gopala Y. M. (2013). 'An Analysis of Knowledge Level of farmers on Utilisation of ICT Tools for Farm Communication' Journal of Rural Development, 32:3, 301 - 310, NIRD, Hyderabad.

Mtega, W.P and Msungu, A.C. (2013) Using Information and Communication Technologies for enhancing the accessibility of agricultural information for improved agricultural production in Tanzania. The Electronic Journal on Information Systems in Developing Countries $56 \quad$ (1), 1-14. http://www.ejisdc.org/ojs2/index.php/eji sdc/article/viewFile/1110/457.

Munyua, H. (2000) Information and Communication Technologies for rural development and food security: Lessons from field experiences in developing countries. Sustainable Development Department (SD), FAO of the United Nations.

Nakweya (2013) Radio, mobile phones could boost African farm yields. http://www.scidev.net/sub-saharanafrica/icts/news/radio-mobile-phonescould-boost-african-farm-yields.html.

Nazari M.R. and Hasbullah, A.H. (2008) Farmers' approach and access to information and communication technology in the efficient use of modern irrigation methods. European Journal of Scientific Research,. 21:1, 
$38-44$.

Okello., Juma, J., Okello, R.M. and Adera, O.E. (2010) Awareness and the use of mobile phones for market linkage by smallholder farmers in Kenya. In: B. M. Maumbe, (ed) e-Agriculture and $e$ Government for Global Policy Development: Implications and Future Direction. Hershey: Information Science Reference, pp: 1-18., doi: 10.4018/978-1-60566-820-8.ch001

Olaniyi, O.A. (2013) Assessment of utilization of Information and Communication Technologies (ICTs) among poultry farmers in Nigeria: an Emerging Challenge. Journal of Animal Science Advances, 3(7):361-369.

One World Foundation India (2012) Model evillages in North-East India: An ICT project for development in remote tribal areas.

http://www.indiagovernance.gov.in/files le-model-village_gkc.pdf.

Oyeyinka, R.A. and Bello, R.O. (2013) Farmers Use of ICTs for Marketing Information Outlets in Oyo State, Nigeria. Journal of Agricultural Science, 5(11): 150-158. doi: 10.5539/jas.v5n11p150

Rajni Jain, Usha Rani Ahuja and Anjani Kumar (2012). 'ICTs and Farm Women: Access, Use and Impact' Ind. Jn. of Agri. Econ., 67:3, July-Sept.
Rebekka Syiem, Saravanan Raj. (2015). 'Access and Usage of ICTs for Agriculture and Rural Development by the tribal farmers in Meghalaya State of North-East India' Journal of Agricultural Informatics (ISSN 2061862X) 6:3, 24-41

Sharma, M., Kaur, G. and Gill, M.S. (2012) Use of Information and Communication Technology in agriculture by farmers of Kapurthala District Journal of Krishi Vigyan Kendra, 1:1, 82-89.

Shetto, M.C. (2008) Assessment of agricultural information needs In African, Caribbean and Pacific (ACP) States Eastern Africa Country Study: Tanzania. Ministry of Agriculture, Food Security and Cooperatives on behalf of the Technical Centre for Agricultural and Rural Cooperation (CTA). http://icmpolicy.cta.int/filesstk/Tanzania _Final-report-081209.pdf.

Sife, A., Kiondo, E. and Lyimo-Macha, J. G. (2010) Contribution of mobile phones to rural livelihoods and poverty reduction in Morogoro Region, Tanzania. The Electronic Journal on Information Systems in Developing Countries 42:3, 1-15. http://www.ejisdc.org/ojs2../ index.php/ejisdc/article/viewFile/660/32 3.

\section{How to cite this article:}

Puri, S. G., C. M. Bellurkar and More, S. G. 2020. Situational Analysis of Farmers on Knowledge and Use of ICT in Agriculture and Allied Sectors. Int.J.Curr.Microbiol.App.Sci. 9(01): 2135-2143. doi: https://doi.org/10.20546/ijcmas.2020.901.243 